\title{
In vitro Antibacterial Properties of Etlingera elatior Flower Extracts against Acne-Inducing Bacteria: Propionibacterium acnes and Staphylococcus aureus
}

\author{
Nurul Saidah $D^{a}$, Salwani $I^{a *}$, Mohd Hilmi $A B^{b}$, Mohd Khairi $Z^{b}$, Rabiatul Adawiyah $U^{a}$, Nurul 'Adani $S^{a}$ \\ ${ }^{a}$ Faculty of Medicine, Universiti Sultan Zainal Abidin (UniSZA), Medical Campus \\ ${ }^{b}$ Faculty of Health Sciences, Universiti Sultan Zainal Abidin (UniSZA), Gong Badak Campus
}

\section{ABSTRACT}

Introduction: Acne is a common skin disorder and is generally caused by Propionibacterium acnes and Staphylococcus aureus. Etlingera elatior flower extract is known to have antibacterial properties however, the properties against these bacteria have not been extensively reported. Thus, this study aimed to investigate the antibacterial properties of the flower extract against these bacteria. Materials and Methods: The flower extract was subjected to sequential extraction using three different solvent polarities; n-Hexane, dichloromethane (DCM) and ethanol. The antibacterial properties were evaluated using the disc diffusion and broth dilution assays techniques by determining the inhibition zone diameter, minimum inhibitory concentration (MIC) and minimum bactericidal concentration (MBC). Total phenolic acids (TPC) and flavonoids contents (TFC) were estimated using Folin-Ciocalteu and aluminium-chloride colorimetric assay respectively. Morphological changes of the treated bacteria were studied using scanning electron microscope (SEM). Results: DCM flower extract showed the highest antibacterial properties against $P$. acnes; at $25 \mathrm{mg} / \mathrm{ml}$ it had the widest inhibition zone $(11.39 \pm 0.45 \mathrm{~mm})$ and the lowest MIC $(6.25 \mathrm{mg} /$ $\mathrm{mL})$ and $M B C(12.5 \mathrm{mg} / \mathrm{mL})$. The ethanolic flower extract had the highest antibacterial properties against S. aureus; at $50 \mathrm{mg} / \mathrm{ml}$ - the inhibition zone was $6.21 \pm 0.25 \mathrm{~mm}$ and the MIC and MBC were both $12.5 \mathrm{mg} /$ $\mathrm{mL}$. Ethanolic extracts had the highest TPC $(966.304 \pm 114.08 \mathrm{mg} \mathrm{GAE} / \mathrm{g})$ and TFC $(796.33 \pm 65.78 \mathrm{mg}$ QE/ $\mathrm{g})$. There was significant morphological changes of the treated bacteria observed under SEM. Conclusion: $\mathrm{E}$. elatior flower extracts exhibited antibacterial properties against acne-inducing bacteria.

KEYWORDS: Antibacterial properties, Etlingera elatior flower, Acne-inducing bacteria.

\section{INTRODUCTION}

Acne is one of the most common skin disorder and primarily appears in areas rich in pilosebaceous units. It represents a significant challenge to dermatologist due to its range of clinical presentation, complexity and prevalence. The various clinical appearances of acne include inflammatory lesions, non-inflammatory lesions, seborrhoea, post inflammatory hyperpigmentation, and variable degrees of disfiguring scars. ${ }^{1}$ Acne is a multifactorial disease and one of the acne

Corresponding author:

Assoc. Prof. Dr. Salwani binti Ismail

Faculty of Medicine, Universiti Sultan Zainal Abidin (UniSZA), Medical Campus, Jalan Sultan Mahmud, 20400 Kuala Terengganu, Terengganu, Malaysia. Tel No: $+6096688558 / 5670$

Email: salwani@unisza.edu.my pathogenesis is colonization of bacteria. According to Lee et al., Propionibacterium acnes and Staphylococcus aureus are the major pathogens and most abundant bacteria on the surface of acneaffected skin. ${ }^{2}$

Acne rarely causes death but the psychological stress due to scars and pustule lesions especially on the face may lead to high emotional impact on a patient's life. ${ }^{3}$ The long term use of antibiotics such as erythromycin and clindamycin against acne may lead to increase the prevalence of antimicrobial resistant organisms, while other treatments for acne such as hormones and isotretinoin may cause many unwanted side effects.

Etlingera elatior or torch ginger is a medicinal plant under the botanical family of Zingiberaceae. It is highly prevalent in South East Asia and is a native 
herbaceous perennial plant to Malaysia. E. elatior flowers also known locally as 'bunga kantan' are available as an ingredient for local products such as soap, shampoo and perfume and known for its antimicrobial and antioxidant properties. ${ }^{4}$ Previous study by Lachumy et al. reported the pharmacological properties of $E$. elatior flower extracts and its potential to be developed as a natural-product based remedy. ${ }^{5}$

Herbal and botanically derived treatment are becoming increasingly popular as an alternative treatment for acne because they are readily available over-the-counter and generally considered as safe remedies. Daud et al. believed that medicinal plant extracts have fewer side effects than synthetic agents do in topical acne treatment. ${ }^{6}$

The antibacterial properties of $E$. elatior flower extracts have been widely reported by previous studies. Lachumy et al. reported that methanol extract of $E$. elatior flower has antimicrobial properties against common human pathogens such as Staphylococcus aureus, Escherichia coli, Bacillus thuringiensis, Bacillus subtilis, Microccocus spp., Salmonella spp, Proteus mirabilis, Aspergillus niger and Candida albicans. ${ }^{5}$ According to Wijekoon et al. the extracted essential oil and the crude solvent extracts of $E$. elatior flower using distilled water, absolute ethanol, and $50 \%$ ethanol as solvents exhibited antibacterial properties against Bacillus subtilis, Staphylococcus aureus, Listeria monocytogenes, and Klebsiella pneumonia. ${ }^{7}$ Ghasemzadeh et al. revealed that aqueous and ethanolic extracts of $E$. elatior flower have antibacterial properties against Staphylococcus aureus, Bacillus subtilis, Pseudomonas aeruginosa, Listeria monocytogenes, Escherichia coli and Salmonella Typhimurium. ${ }^{8}$ All these studies however were conducted using a single solvent extraction method. To date, there are no extensive studies reported on the antibacterial properties of the $E$. elatior flower extracts using three different polarities of solvents namely $n$-Hexane (nonpolar), DCM (semipolar) and ethanol (polar) against acneinducing bacteria: $P$. acnes and $S$. aureus. Thus, this study aimed to investigate the antibacterial properties of $E$. elatior flower extract using three different polarities of solvents namely $\mathrm{n}$-Hexane (nonpolar), dichloromethane (DCM) (semi-polar) and ethanol (polar) against acne inducing bacteria, $S$. aureus and $P$. acnes.

\section{MATERIALS AND METHODS}

\section{Preparation of Etlingera elatior flower}

Fresh and young light pink flowers of Etlingera elatior were collected from Kelantan, Malaysia. The collected flowers were verified as $E$. elatior at the Faculty of Bioresources and Food Industry, UniSZA with the voucher number 000346 . The flowers were washed under running tap water, dried in the oven at $50^{\circ} \mathrm{C}$. The dried flowers were blended into coarse powder and later stored at room temperature.

\section{Preparation of Etlingera elatior flowers extracts}

The flower in powdered form were subjected to sequential extraction starting with n-hexane (nonpolar), dichloromethane (DCM) (semi-polar) and ethanol (polar). ${ }^{9}$ The chemical solvents used were analytical grade chemicals from Sigma-Aldrich ${ }^{\circledR}$. The respective extracts were collected and dried under reduced pressure at $50^{\circ} \mathrm{C}$ using rotary vacuum evaporator. In this study, the solvents were removed based on the setting pressure programed by Eyela vacuum controller NVC-2300 at 160, 480 and $67 \mathrm{hPa}$ respectively. The final weight of each extract were taken three times until a constant weight of each extract was achieved. It was to ensure that all of the respective solvents used (nhexane, DCM and ethanol) had completely evaporated. The crude extracts were stored at $4^{\circ} \mathrm{C}$ until further use. The stock solution for each E.elatior flower extract was prepared by dissolving $0.1 \mathrm{~g}$ of extract in $1 \mathrm{~mL}$ of $100 \%$ dimethyl sulphate oxide (DMSO) to produce a final concentration of $100 \mathrm{mg} / \mathrm{mL}$.

\section{Inoculum preparation}

The two test bacteria were obtained from the American Type Culture Collection (ATCC) ${ }^{\circledR}$. Propionibacterium acnes (ATCC 6919) and Staphylococcus aureus (ATCC 9144) were used in this study. $P$. acnes was verified using Gram-staining method, catalase and indole tests; while Gramstaining, catalase and coagulase tests were used to verify S. aureus. The inoculum of each bacterium was prepared by subculturing the $P$. acnes in brain heart infusion $(\mathrm{BHI})$ broth with $1 \%$ glucose for 72 hours while $S$. aureus was subcultured in Muller Hinton $(\mathrm{MH})$ broth for 24 hours. All of the culture media used in this study were purchased from 
Thermo Scientific ${ }^{\mathrm{TM}}$ Oxoid. The optical density (OD) of each inoculum suspensions was adjusted to reach 0.5 McFarland $\left(1.5 \times 10^{8} \mathrm{CFU} / \mathrm{ml}\right){ }^{10}$

\section{Susceptibility testing}

Two fold serial dilution of each extract was prepared to reach $100,50,25,12.5,6.25,1.25$, 0.75 and $0.39 \mathrm{mg} / \mathrm{mL}$ concentration by dissolving with DMSO.

\section{Disk diffusion assay}

Disk diffusion assay was performed according to Aziman et al. ${ }^{11}$ Sterile paper disks $(6 \mathrm{~mm}$ in diameter) were impregnated with 100, 50, 25 and $12.5 \mathrm{mg} / \mathrm{mL}$ concentration of each extract. The impregnated, negative and positive control disks were then placed onto the $\mathrm{BHI}$ and $\mathrm{MH}$ agar. The negative control disk was prepared by impregnating $100 \%$ DMSO. Clindamycin ( $2 \mu \mathrm{g} /$ disk) and oxacillin $(1 \mu \mathrm{g} /$ disk) were used as positive control disks for $P$. acnes and S. aureus, respectively. The plates were then incubated anaerobically for 72 hours at $37^{\circ} \mathrm{C}$ for $P$. acnes while aerobically for 24 hours at $37^{\circ} \mathrm{C}$ for $S$. aureus. All disk diffusion tests were performed in triplicate and the antibacterial activity was expressed as the mean of inhibition zone diameters.

\section{Broth dilution assay}

\section{Determination of Minimum Inhibitory} Concentration (MIC)

The MIC was determined by using broth microdilution assay. ${ }^{12}$ Two fold serial dilution of each extract was prepared to reach 100,50 , $25, \quad 12.5, \quad 6.25, \quad 1.25, \quad 0.75$ and $0.39 \mathrm{mg} / \mathrm{mL}$ concentration in a 96-well enzyme-linked immunosorbent assay (ELISA) plate. Fifty (50) $\mu \mathrm{L}$ of inoculum suspension of each bacteria was added to each well. The 96-well ELISA plates were incubated for 72 hours at $37^{\circ} \mathrm{C}$ anaerobically for $P$. acnes and at $37^{\circ} \mathrm{C}$ for 24 hours for S. aureus. After incubation, $10 \mu \mathrm{L}$ of resazurin solution (R\&D System ${ }^{\circledR}$ AR002) was added to each well and was further incubated for 4 hours for the observation of colour change. The living cells will reduce the blue dye of resazurin to pink while the dead cells will maintain the blue colour. ${ }^{13} \mathrm{MIC}$ value of the extract was taken as the lowest concentration of the extract that managed to maintain the blue colour of resazurin.

\section{Determination of Minimum Bactericidal Concentration $(M B C)$}

The $M B C$ was determined according to Witkowska et al. ${ }^{14}$ Five (5) $\mu \mathrm{l}$ of the suspension from the MIC wells was subcultured on $\mathrm{BHI}$ agar and $\mathrm{MH}$ agar plates for $P$. acnes and $S$. aureus respectively. The plates were incubated anaerobically at $37^{\circ} \mathrm{C}$ for 72 hours for $P$. acnes and aerobically at $37{ }^{\circ} \mathrm{C}$ for 24 hours for $S$. aureus. The MBC was defined as the lowest concentration of the extract, which killed $99 \%$ of the bacteria. ${ }^{15}$

\section{Estimation of Total Phenolic Acids Compound (TPC)}

TPC of the extracts was estimated using FolinCiocalteu method. ${ }^{16}$ All the chemicals and reagents used were analytical grade chemicals. One (1) $\mathrm{ml}$ of the individual extract was diluted in $10 \mathrm{ml}$ distilled water. The solution then was mixed with $1.5 \mathrm{ml}$ of Folin-Ciocalteu's phenol reagent and was allowed to stand at room temperature for 5 minutes. Four (4) $\mathrm{ml}$ of $20 \%$ sodium carbonate solution was added to the mixture and the volume was adjusted by adding distilled water to reach $25 \mathrm{ml}$. The reaction mixtures were then incubated at room temperature for 30 minutes. The absorbance of the mixture at $765 \mathrm{~nm}$ was measured by a spectrophotometer (Thermo Genesys $^{\text {TM }} 20$ Visible Spectrophotometer). The blue coloration produced is proportionate to the total amount of phenolic acids compounds originally present in the extracts. ${ }^{17} \mathrm{~A}$ dose response linear regression curve was generated by using the Gallic acid standard absorbance and the results were expressed as ' $m g$ of Gallic acid equivalent (GAE) per gram of extract'.

\section{Estimation of Total Flavonoids Compound (TFC)}

TFC was estimated by aluminium chloride method. ${ }^{16}$ All the chemicals and reagents used were analytical grade chemicals. $0.5 \mathrm{ml}$ of each extract was mixed with $1.5 \mathrm{ml} 95 \%$ methanol, $0.1 \mathrm{ml}$ of $10 \%$ aluminium chloride, $0.1 \mathrm{ml}$ of $1 \mathrm{M}$ potassium acetate and $2.8 \mathrm{~mL}$ of distilled water. The solution was mixed well and kept for 30 minutes at room temperature. The absorbance for each sample was measured at $415 \mathrm{~nm}$ by a spectrophotometer. The TPC was calculated using a standard Quercetin calibration curve. The 
results were expressed as 'mg of Quercetin equivalent $(\mathrm{QE})$ per gram of extract'.

Morphological study under scanning electron microscope (SEM)

The prepared inocula of $P$. acnes and S. aureus were treated with one $\mathrm{mL}$ of $\mathrm{n}$-hexane, dichloromethane and ethanolic extracts of $E$. elatior flower at their respective MIC value and were incubated at $37^{\circ} \mathrm{C}$ anaerobically for 72 hours for $P$. acnes and aerobically for 24 hours for $S$. aureus. Untreated $P$. acnes and S. aureus were also prepared as control samples. After incubation, all the test and control samples were centrifuged at $1500 \mathrm{G}$ for 10 minutes to obtain cell pellet. The samples were washed five times with fresh media and then fixed with 2.5\% glutaraldehyde in $0.1 \mathrm{M}$ sodium cacodylate buffer at $4^{\circ} \mathrm{C}$ for 1 hour before rinsing three times with $0.1 \mathrm{M}$ sodium cacodylate buffer, $\mathrm{pH} 7.2$ for 10 minutes and fixed with $1 \%$ osmium tetroxide, $\mathrm{pH} 7.2$ for 2 hours. The obtained cell pellets were rinsed three times with $0.1 \mathrm{M}$ sodium cacodylate buffer $(\mathrm{pH} 7.2)$ and dehydrated with $25 \%, 50 \%, 75 \%, 90 \%$, and $100 \%$ ethanol for 10 minutes each. All the chemicals and reagents used were analytical grade chemicals. The samples were dried using critical point dryer (CPD) before being mounted on carbon stub and sputtercoated with gold in an ion coater. The mounted samples were observed by microscopic examination using SEM (JEOL 6360 LA).

\section{RESULTS}

\section{Antibacterial properties of Etlingera elatior flower extracts}

The inhibition zone diameter of the extracts against $P$. acnes and S. aureus is shown in Table 1 and the MIC and MBC values are shown in the Table 2. All types of extracts exhibited antibacterial properties against the bacteria. DCM extract showed the highest antibacterial properties against $P$. acnes, at $25 \mathrm{mg} / \mathrm{ml}$ it has the widest inhibition zone $(11.39 \pm$ $0.45 \mathrm{~mm})$ and the lowest MIC $(6.25 \mathrm{mg} / \mathrm{mL})$ and $M B C$ $(12.5 \mathrm{mg} / \mathrm{mL})$. The ethanolic extract of the flower has the highest antibacterial properties against $S$. aureus; at $50 \mathrm{mg} / \mathrm{ml}$ the inhibition zone was $6.21 \pm$ $0.25 \mathrm{~mm}$ and the MIC and MBC were both $12.5 \mathrm{mg} /$ $\mathrm{mL}$. The negative control (DMSO) demonstrated no inhibition zones.
Total phenolic acids and flavonoid contents of Etlingera elatior flower extracts

The total phenolic content (TPC) and total flavonoid content (TFC) of the $E$. elatior flower extracts are shown in Table 3. TPC is expressed as Gallic acid equivalent (GAE) (the standard curve equation: $y=$ $\left.0.9614 x+0.0605 ; R^{2}=0.9955\right)$ while TFC is expressed as Quercetin equivalent (the standard curve equation: $\left.y=0.6447 x-0.0259 ; R^{2}=0.9909\right)$. The highest TPC value was detected in the ethanolic extract $(966.304 \pm 114.08 \mathrm{mg} \mathrm{GAE} / \mathrm{g})$, followed by DCM extract (110 $\pm 26.75 \mathrm{mg} \mathrm{GAE} / \mathrm{g})$ and $\mathrm{n}$-Hexane extract $(79.398 \pm 38.49 \mathrm{mg} \mathrm{GAE} / \mathrm{g})$. For TFC, the highest value was demonstrated in the ethanolic extract $(796.33 \pm 65.78 \mathrm{mg} \mathrm{QE} / \mathrm{g})$, followed by DCM extract $(444.34 \pm 85.09 \mathrm{mg} \mathrm{QE} / \mathrm{g})$ and $\mathrm{n}$-Hexane extract $(107.23 \pm 11.75 \mathrm{mg} \mathrm{QE} / \mathrm{g})$.

\section{Morphological study under scanning electron microscope (SEM)}

The morphological changes of the treated $P$. acnes and S. aureus were viewed under SEM at 15000 times magnification. All of the treated $P$. acnes demonstrated significant morphological changes compared to the untreated $P$. acnes that displayed smooth branched pleomorphic rod-shaped bacteria (Figures $1 \mathrm{~A}, \mathrm{~B}, \mathrm{C}$, and $\mathrm{D}$ ). The $\mathrm{n}$-Hexane extract treated $P$. acnes bacteria were found to have distorted shape with formation of multiple pores noted as shown in Figure 1B. DCM extract treated $P$. acnes demonstrated distorted cells with holes formation as shown in the Figure $1 C$ while the ethanolic extract treated $P$. acnes cells appeared to be disfigured, shorten and flatten (Figure 1D).

Regarding S. aureus, all of the treated S. aureus also demonstrated significant morphological changes compared to the untreated $\mathrm{S}$. aureus that appeared as cocci shaped bacteria arranged in clusters (Figures $2 \mathrm{~A}, \mathrm{~B}, \mathrm{C}$ and D). The $\mathrm{n}$-Hexane treated $\mathrm{S}$. aureus demonstrated irregular, rough surface cells with pores formation as shown in the Figure $2 \mathrm{~B}$. The DCM extract treated $S$. aureus were observed to have the same features as $\mathrm{n}$-Hexane extract treated $S$. aureus plus the presence of ruptured cells (Figure 2C) while in Figure 2D, majority of the cells of the ethanolic extract treated $\mathrm{S}$. aureus were ruptured and appeared clumping to each other. 
Table 1 Inhibition zone diameter of Etlingera elatior flower extracts against Propionibacterium acnes and Staphylococcus aureus

\begin{tabular}{|c|c|c|c|c|c|c|}
\hline \multirow[b]{2}{*}{ Bacteria } & \multirow{2}{*}{$\begin{array}{l}\text { Concentration } \\
(\mathrm{mg} / \mathrm{mL})\end{array}$} & \multicolumn{5}{|c|}{ Zone of inhibition $(\mathrm{mm})$} \\
\hline & & $\begin{array}{c}\text { n-Hexane } \\
\text { extract }\end{array}$ & DCM extract & Ethanol extract & Positive control & $\begin{array}{c}\text { Negative } \\
\text { control }\end{array}$ \\
\hline \multirow{4}{*}{ P. acnes } & 12.5 & 0 & 0 & 0 & \multirow{4}{*}{$54.29 \pm 1.39$} & \multirow{4}{*}{0} \\
\hline & 25 & $6.33 \pm 0.00$ & $7.89 \pm 0.20$ & $7.04 \pm 0.00$ & & \\
\hline & 50 & $6.57 \pm 0.11$ & $8.88 \pm 0.42$ & $7.40 \pm 0.16$ & & \\
\hline & 100 & $7.55 \pm 0.50$ & $11.39 \pm 0.45$ & $7.61 \pm 0.25$ & & \\
\hline \multirow{4}{*}{ S. aureus } & 12.5 & 0 & 0 & 0 & \multirow{4}{*}{$30.75 \pm 0.69$} & \multirow{4}{*}{0} \\
\hline & 25 & 0 & 0 & 0 & & \\
\hline & 50 & 0 & 0 & $6.21 \pm 0.25$ & & \\
\hline & 100 & 0 & $7.71 \pm 0.07$ & $6.43 \pm 0.43$ & & \\
\hline
\end{tabular}

\section{DISCUSSION}

MIC is defined as the least concentration of the plant extracts that can inhibit the growth of bacteria (bacteriostatic) while $M B C$ is the lowest concentration of plant extract that can killed $99 \%$ of the bacteria (bactericidal). ${ }^{18}$ In this study, all types of $E$. elatior flower extract were found to have both bacteriostatic and bactericidal effect against acne inducing bacteria namely $P$. acnes and $S$. aureus. As shown by the individual MIC and MBC values (Table 2).

Table 2 Minimum inhibitory concentration (MIC) and minimum bactericidal concentration (MBC) of Etlingera elatior flower extracts against Propionibacterium acnes and Staphylococcus aureus

\begin{tabular}{ccccc}
\hline & \multicolumn{2}{c}{$\begin{array}{c}\text { Propionibacterium } \\
\text { Tycnes }\end{array}$} & \multicolumn{2}{c}{$\begin{array}{c}\text { Staphylococcus } \\
\text { aureus }\end{array}$} \\
\cline { 2 - 5 } Extraction & $\begin{array}{c}\mathrm{MIC} \\
(\mathrm{mg} / \mathrm{ml})\end{array}$ & $\begin{array}{c}\mathrm{MBC} \\
(\mathrm{mg} / \mathrm{ml})\end{array}$ & $\begin{array}{c}\mathrm{MIC} \\
(\mathrm{mg} / \mathrm{ml})\end{array}$ & $\begin{array}{c}\mathrm{MBC} \\
(\mathrm{mg} / \mathrm{ml})\end{array}$ \\
\hline $\mathrm{n}$-Hexane & 6.25 & 25 & 12.5 & 50 \\
$\begin{array}{c}\text { Dichloro- } \\
\text { methane }\end{array}$ & 1.56 & 6.25 & 6.25 & 25 \\
Ethanol & 12.5 & 12.5 & 12.5 & 12.5 \\
\hline
\end{tabular}

Based on the results, DCM and ethanol were found to be the most effective solvents for extracting the antibacterial agents from E. elatior flowers against $P$. acnes and S. aureus. Study by Sharifi-Rad et al. revealed that antibacterial activities of plants were contributed by various classes of secondary metabolites, including fatty acids, sterols, alkaloids, flavonoids and phenolic acids compounds. ${ }^{19}$ Less polar flavonoids for examples isoflavones and flavonols are generally extracted by semi-polar solvents while polar flavonoids such as anthocyanidins are generally extracted with polar solvents. ${ }^{20}$ This evidence support the highest antibacterial properties demonstrated by the ethanolic and DCM extracts of E. elatior flower.

Table 3 Total phenolic content (TPC) and total flavonoid content (TFC) of Etlingera elatior flower extracts

\begin{tabular}{ccc}
\hline Extracts & $\begin{array}{c}\text { Total phenolic } \\
\text { acids compound } \\
\text { (mg of GAE/g of } \\
\text { extract) }\end{array}$ & $\begin{array}{c}\text { Total flavonoids } \\
\text { compound } \\
\text { (mg QE/g of } \\
\text { extract) }\end{array}$ \\
\hline $\begin{array}{c}\text { n-Hexane } \\
\begin{array}{c}\text { Dichloro- } \\
\text { methane }\end{array}\end{array}$ & $79.398 \pm 38.49$ & $107.23 \pm 11.75$ \\
Ethanol & $966.304 \pm 114.08$ & $796.33 \pm 65.78$ \\
\hline
\end{tabular}

In this study, all different polarities of E. elatior flower extracts contained phenolic acids and flavonoids compounds which is in agreement with previous study on phytochemical screening of $E$. elatior flower extracts. ${ }^{21}$ The degree of plant bioactive constituents solubility depends on the solvent used and different solvents have diverse solubility capacities for different phytochemicals. ${ }^{22}$ Ethanolic extract was found to have the highest TPC and TFC compared to DCM and n-Hexane extracts. This is due to the characteristic of phenolic acids and flavonoids that are more extractable in polar solvent such as ethanol. ${ }^{23}$ According to Abdul Mutalib et al. ethanol was found easier to alter polyphenol oxidases and cause degradation to the cell wall, thus extracting more endocellular constituents from the plant extract. ${ }^{24}$

Based on SEM analysis, the morphological changes of the bacteria are believed to be due to the binding of E. elatior active component to the membrane-bound enzyme and the phospholipid bilayer of the cytoplasmic membrane of the bacteria. ${ }^{25}$ 


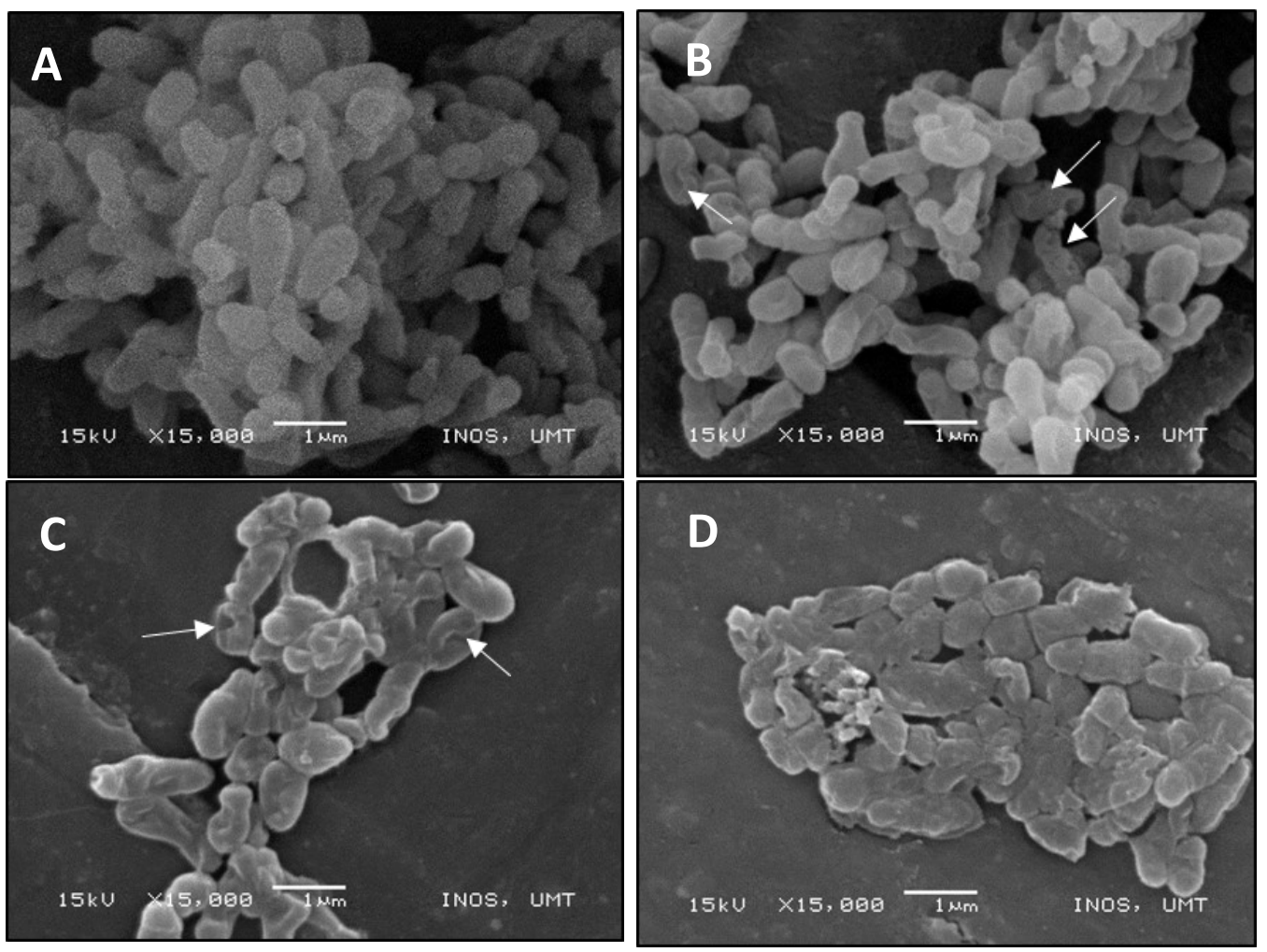

Figure 1 Scanning electron micrograph (SEM) of Propionibacterium acnes (A) Untreated P. acnes displayed smooth branched pleomorphic rod-shaped bacteria; (B) $n$-Hexane extract-treated $P$. acnes demonstrated distorted shape with formation of multiple pores as shown with arrows; (C) DCM extract-treated $P$. acnes demonstrated distorted cells with holes formation as shown with arrows; (D) ethanolic extract-treated $P$. acnes appeared to be disfigured, shorten and flatten.
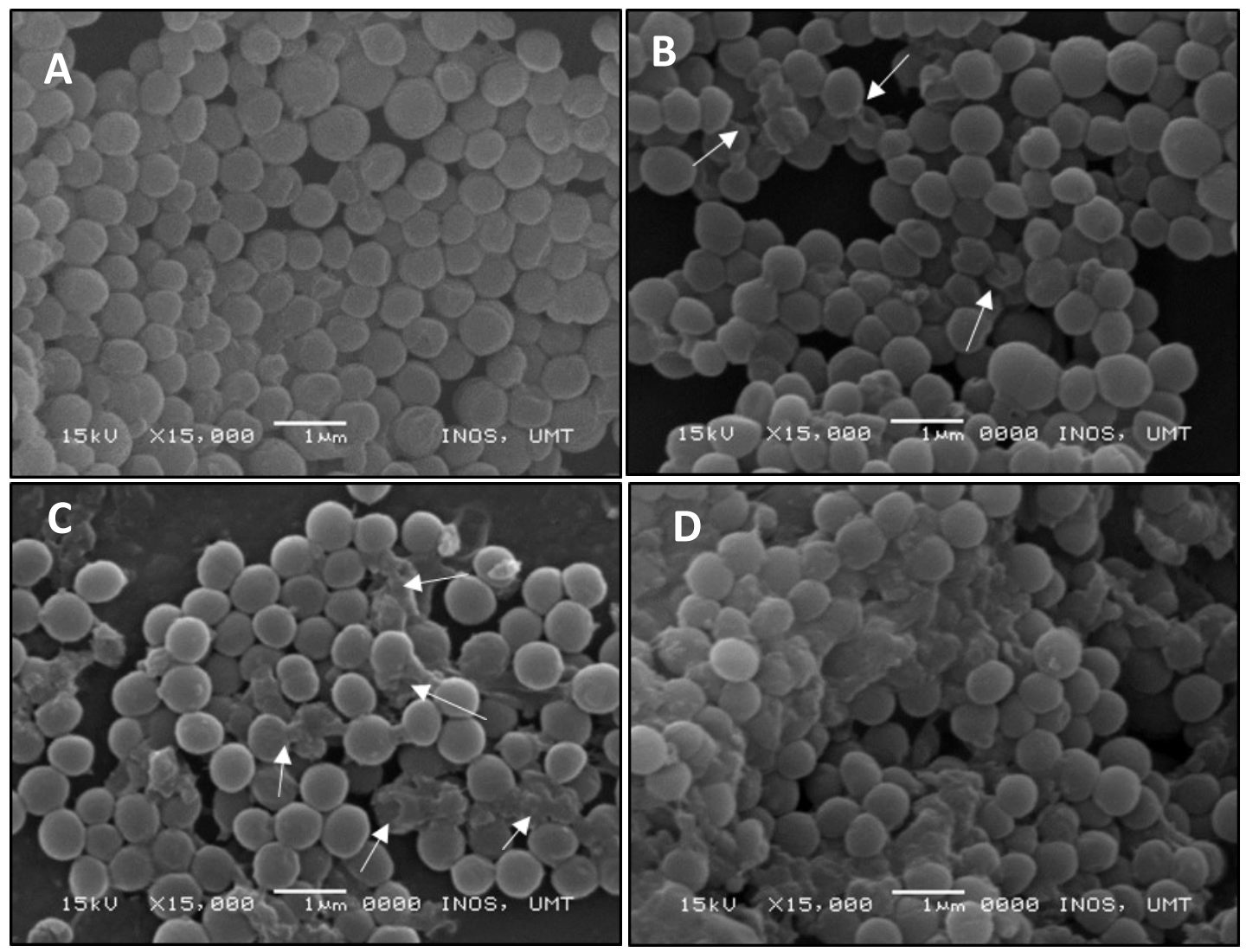

Figure 2: Scanning electron micrograph (SEM) of Staphylococcus aureus (A) Untreated S. aureus appeared as cocci shaped bacteria arranged in clusters; (B) n-Hexane-treated S. aureus appeared irregular, rough surface with pores formation as shown with arrows; (C) DCM extract-treated S. aureus demonstrated irregular, rough surface, pores formation with the presence of ruptured cells as shown with arrows; (D) ethanolic extract-treated S. aureus were ruptured and appeared clumping to each other. 
The damaged of the cytoplasmic membrane and cell wall of the bacteria led to the loss of structural integrity and the ability of the membrane to act as a permeability barrier. ${ }^{26}$ The extensive loss of cell contents, the initiation of autolytic processes and the leakage of critical cell components resulted to bacterial cell death. ${ }^{27,28}$

\section{CONCLUSION}

Etlingera elatior flower extracts exhibited significant antibacterial properties against acne inducing bacteria namely Propionibacterium acnes and Staphylococcus aureus. This result suggests that $E$. elatior flower extracts could potentially be used as alternative treatment agents against acne inducing bacteria.

\section{CONFLICT OF INTEREST}

We (authors) would like to declare that there is no conflict of interests in this study.

\section{ACKNOWLEDGEMENTS}

The authors are grateful to the authorities of Faculty of Medicine and Faculty of Bioresources and Food Industry of Universiti Sultan Zainal Abidin (UniSZA) and Institute of Oceanography and Environment (INOS) of Universiti Malaysia Terengganu (UMT) for the laboratory facilities.

\section{REFERENCES}

1. Keyal U, Bhatta AK, Wang XL. Photodynamic therapy for the treatment of different severity of acne: A systematic review. Photodiagnosis and Photodynamic Therapy 2016;14:191-199.

2. Lee CJ, Chen LG, Liang WL, Wang CC. Multiple activities of Punica granatum linne against acne vulgaris. International Journal of Molecular Sciences 2017;18,141:1-12.

3. Chen HY, Lin YH, Chen YC. Identifying Chinese herbal medicine network for treating acne: Implications from a nationwide database. Journal of Ethnopharmacology 2016;179:1-8.

4. Aziman N, Abdullah N, Mohd Noor Z, Zulkifli KS, Wan Kamarudin WSS. Phytochemical constituents and in vitro bioactivity of ethanolic aromatic herb extracts. Sains
Malaysiana 2012;41:1437-1444.

5. Lachumy SJT, Sasidharan S, Sumathy V, Zuraini Z. Pharmacological activity, phytochemical analysis and toxicity of methanol extract of Etlingera elatior (torch ginger) flowers. Asian Pacific Journal of Tropical Medicine 2010;3:769-774.

6. Daud FS, Pande G, Joshi M, Pathak R, Wankhede S. A study of antibacterial effect of some selected essential oils and medicinal herbs against acne causing bacteria. International Journal of Pharmaceutical Science Invention 2013;2:27-34.

7. Wijekoon MMJO, Bhat R, Karim AA, Fazilah A. Chemical composition and antimicrobial activity of essential oil and solvent extracts of torch ginger inflorescence (Etlingera elatior Jack.). International Journal of Food Properties 2013;16:1200 -1210.

8. Ghasemzadeh A, Jaafar HZE, Rahmat A, \& Ashkani S. Secondary metabolites constituents and antioxidant, anticancer and antibacterial activities of Etlingera elatior (Jack) R.M.Sm grown in different locations of Malaysia. BMC Complementary and Alternative Medicine 2015;15:335:1-10.

9. Jeyaseelan EC, Jenothiny S, Pathmanathan MK, Jeyadevan JP. Antibacterial activity of sequentially extracted organic solvent extracts of fruits, flowers and leaves of Lawsonia inermis $L$. from Jaffna. Asian Pacific Journal of Tropical Biomedicine 2012;2:798-802.

10. Clinical and Laboratory Standards Institute. Performance standards for antimicrobial susceptibility testing. Nineteenth informational supplement M100-S19. Wayne, PA: Clinical and Laboratory Standards Institute; 2009.

11. Aziman N, Abdullah N, Noor ZM, Kamarudin WSSW, Zulkifli KS. Phytochemical profiles and antimicrobial activity of aromatic Malaysian herb extracts against food-borne pathogenic and food spoilage microorganisms. Journal of Food Science 2014;79:583-592.

12. Balouiri M, Sadiki M, Ibnsouda SK. Methods for in vitro evaluating antimicrobial activity: A review. Journal of Pharmaceutical Analysis 2016;6:71-79.

13. Sarker SD, Nahar L, Kumarasamy Y. Microtitre plate-based antibacterial assay incorporating resazurin as an indicator of cell growth, and its application in the in vitro antibacterial 
screening of phytochemicals. Methods 2007; 42: 321-324.

14. Witkowska AM, Hickey DK, Alonso-Gomez M, Wilkinson M. Evaluation of antimicrobial activities of commercial herb and spice extracts against selected food-borne bacteria. Journal of Food Research 2013;2:37 -54 .

15. Zainol MI, Mohd Yusoff K, Mohd Yusof MY. Antibacterial activity of selected Malaysian honey. BMC Complementary and Alternative Medicine 2013;13:129.

16. Madaan R, Kumar S, Bansal G, Sharma A. Estimation of total phenols and flavonoids in extracts of Actaea spicata roots and antioxidant activity studies. Indian Journal of Pharmaceutical Sciences 2011;73:666-669.

17. Kamtekar S, Keer V, Patil V. Estimation of phenolic content, flavonoid content, antioxidant and alpha amylase inhibitory activity of marketed polyherbal formulation. Journal of Applied Pharmaceutical Science 2014; 4: 61-65.

18. Raja Mazlan RNA, Rukayadi Y, Maulidiani M, Ismail IS. Solvent Extraction and Identification of Active Anticariogenic Metabolites in Piper cubeba L. through ${ }^{1} \mathrm{H}$ NMR-Based Metabolomics Approach. Molecules 2018;23:1-19.

19. Sharifi-Rad J, Hoseini-Alfatemi SM, SharifiRad M, Silva JA. Antibacterial, antioxidant, antifungal and anti-inflammatory activities of crude extract from Nitraria schoberi fruits. 3 Biotech 2015;5:677-684.

20. Kashani HH, Hoseini ES, Nikzad H, Aarabi MH. Pharmacological properties of medicinal herbs by focus on secondary metabolites. Life Science Journal 2012;9:509-520.

21. Jackie $T$, Haleagrahara $\mathrm{N}$, Chakravarthi $\mathrm{S}$. Antioxidant effects of Etlingera elatior flower extract against lead acetate - induced perturbations in free radical scavenging enzymes and lipid peroxidation in rats. BMC Research Notes 2011;67:1-8.

22. Shobowale OO, Ogbulie NJ, Itoandon EE, Oresegun MO, Olatope SOA. Phytochemical and antimicrobial evaluation of aqueous and organic extracts of Calotropis procera ait leaf and latex. Nigerian Food Journal 2013;31:7782.

23. Laeliocattleya RA, Estiasih T, Griselda G, Muchlisyiyah J. The bioactive compounds and antioxidant activity of ethanol and ethyl ecetate extracts of Candi Banana (Musa paradisiaca). IOP Conference Series: Earth and Environmental Science 2018:131:1-6.

24. Abdul Mutalib M, Rahmat A, Ali F, Othman F, Ramasamy R. Nutritional compositions and antiproliferative activities of different solvent fractions from ethanol extract of Cyphomandra betacea (Tamarillo) fruit. Malaysian Journal of Medical Sciences 2017;24:19-32.

25. Shan B, Cai Y, Brooks JD, Corke H. Antibacterial properties and major bioactive components of cinnamon stick (Cinnamomum burmannii ): Activity against foodborne pathogenic bacteria. J.Agric. Food Chem. 2007;55:5484-5490.

26. Kim YM, Farrah S, Baney RH. Membrane damage of bacteria by silanols treatment. Electronic Journal of Biotechnology 2007;10:252-259.

27. Sofy AR, Hmed AA, Sharaf AMA and ElDougdoug KA. Structural changes of pathogenic multiple drug resistance bacteria treated with $T$. vulgaris aqueous extract. Nat Sci 2014;12:83-88.

28. Zengin H, Baysal AH. Antibacterial and antioxidant activity of essential oil terpenes against pathogenic and spoilage-forming bacteria and cell structure-activity relationships evaluated by SEM microscopy. Molecules 2014;19:17773-17798. 